\title{
Efficacy of Liquid Feeds Varying in Concentration and Composition of Fat, Nonprotein Nitrogen, and Nonfiber Carbohydrates for Lactating Dairy Cows ${ }^{1}$
}

\author{
J. L. Firkins, ${ }^{2}$ B. S. Oldick, ${ }^{3}$ J. Pantoja, ${ }^{4}$ C. Reveneau, L. E. Gilligan, and L. Carver ${ }^{5}$ \\ Department of Animal Sciences, The Ohio State University, Columbus 43210
}

\section{ABSTRACT}

In trial 1, we evaluated the efficacy of a liquid feed (LF) containing cane molasses and corn steep liquor as carriers of suspended white grease (WG) without or with urea (U) or with soybean lipid (SL; a byproduct of soybean processing) compared with roasted soybeans plus tallow blended into respective concentrates in a 16-wk lactation study. The dry matter intake (DMI) and milk production for LF diets were either similar to or greater than respective controls, although SL decreased milk fat percentage. In trial 2, we compared LF without fat to LF plus WG or SL and also evaluated the dose response to increasing amount of $\mathrm{LF}+\mathrm{WG}$ in a 16-wk lactation trial in which the LF products were added to respective total mixed rations. The DMI was increased and then decreased (quadratic response) with increasing $\mathrm{LF}+\mathrm{WG}$ without a linear response. However, production of milk, protein, and fat increased linearly with corresponding quadratic responses, which we interpret to be a result of a limiting returns response from DMI and density of net energy for lactation. When LF plus SL was fed, milk fat percentage and yield decreased compared with the comparable amount of LF + WG. In a 12 -wk lactation study (trial 3 ), we added 3.25 or $6.5 \%$ of the dry matter as LF (a different but generally similar product than the previous trials and without fat) to diets formulated to maintain comparable ruminal nonstructural carbohydrate digestibility by

Received November 16, 2007.

Accepted January 11, 2008.

${ }^{1}$ Salaries and research support were provided by state and federal funds appropriated to the Ohio Agricultural Research and Development Center, The Ohio State University. Contributing to Regional Research Project NC-1009. Manuscript No. 34/07AS. Additional research support provided by Cargill Molasses Liquid Products Division (Elk River, MN) and by Quality Liquid Feeds (Dodgeville, WI).

${ }^{2}$ Corresponding author: firkins.1@osu.edu

${ }^{3}$ Current address: Kent Feeds, Granger, IN 46530.

${ }^{4}$ Current address: Universidad de Puerto Rico, Mayagüez PR 00681-9000.

${ }^{5}$ Current address: Quality Liquid Feeds, PO Box 240, Dodgeville, WI 53533. adding soybean hulls to decrease nonfiber carbohydrates (NFC) concentration; the $6.5 \% \mathrm{LF}$ diet was without or with Rumensin (11.5 g/909 kg of dry matter). When $3.25 \% \mathrm{LF}$ was added but NFC was decreased from 40 to $37 \%$, cows increased DMI and production of milk fat. Adding Rumensin decreased DMI but maintained milk fat yield compared with its $6.25 \% \mathrm{LF}$ control without Rumensin. In trials 1 and 3, apparent total tract nutrient digestibility was not affected by treatment. In conclusion, feeding LF at about 5\% (trial 2, which contained WG, $1.6 \%$ added sugar) or $3.25 \%$ (trial $3,1.7 \%$ added sugar) generally increased DMI and maintained or increased production of milk, protein, and fat.

Key words: liquid feed, animal fat, monensin, milk fat production

\section{INTRODUCTION}

As milk production potential increases, dairy nutritionists are trying to maximize the intake of digestible carbohydrate while minimizing the risk of metabolic problems such as ruminal acidosis, laminitis, and milk fat depression. As documented by NRC (2001) guidelines, forage NDF must counterbalance the ruminal degradability of NSC (defined as a chemical measure of starch plus sugar). Although the NRC (2001) model provides a processing adjustment factor, it does not account adequately for substantial changes in ruminal availability of NSC, and it provides recommendations for NFC (hereafter referred to as the difference of OM minus CP, fat, and NDF that has been corrected to be CP-free) rather than starch and sugar. Starch can have a variable ruminal digestibility that depends on processing and other factors (Firkins et al., 2001), whereas sugars are assumed to be nearly completely degraded in the rumen and might increase the need for peptides versus $\mathrm{NH}_{3}-\mathrm{N}$ (Firkins et al., 2006). Thus, many dairy nutritionists are concerned about a high inclusion rate of sugars in the diet, which could promote acidosis and sometimes reduce the digestibility of NDF (Piwonka et al., 1994). In contrast, molasses can increase NDF 
digestibility without lowering ruminal $\mathrm{pH}$ (Broderick and Radloff, 2004), although more studies are needed to verify when and why NDF digestibility is increased by sugars.

In addition to serving as a highly digestible energy course, liquid feeds $(\mathbf{L F})$ are used in the dairy industry for other, nonnutritive reasons. Although DMI was not increased, cows preferred sweetened diets (Murphy et al., 1997), so LF might stimulate DMI in certain dietary conditions in which palatability is decreased. Field observations generally support the potential benefit of LF to decrease cow sorting behavior against long hay particles. Water decreased sorting against dry forage particles (Leonardi et al., 2005), but data are limiting for LF and results for individually fed animals might not represent field expectations (Leonardi and Armentano, 2007). Consequently, although LF are a convenient carrier for various feed ingredients such as NPN, which would require premixing, or supplemental fat, which could require melting before mixing, our aims were restricted to evaluating the nutritional qualities for individually fed cows.

Because LF could decrease ruminal ammonia concentration (Broderick and Radloff, 2004; DeFrain et al., 2006), adding urea to LF might improve its overall efficacy (Sannes et al., 2002). A slow-release source was generally comparable with soybean meal in diets containing sugars (Golombeski et al., 2006). Dietary fat improved milk production, but molasses or whey did not further enhance productivity and, in fact, tended $(P \leq 0.10)$ to decrease milk fat and protein percentages (Maiga et al., 1995). However, in that study, the measured NSC was $>35 \%$, which might be higher than optimal for adding sugars in dairy rations. The calculated NFC was 41 to $42 \%$ and likely would be 2 to 3 percentage units higher if neutral detergent insoluble CP (NDICP) was accounted for in the NFC calculation. Therefore, our hypothesis was that LF in combination with different fat and NPN sources can substitute for typical sources of energy and protein in dairy rations while maintaining milk production or even increasing it if $\mathrm{DMI}$ is stimulated and dietary NFC is kept at moderate concentrations. Our first objective (trial 1) was to evaluate LF as a source of energy, without or with different sources of fat and NPN, with the hypothesis that milk production would be maintained or slightly improved compared with more conventional diets. The fat-containing LF was added in addition to conventional fat sources, including a control with unsaturated fat, to demonstrate that this form of feeding should not be detrimental to NDF digestibility or depress milk fat production appreciably. To differentiate the benefits of added energy from fat that is suspended in LF products, the objective for trial 2 was to compare lactation perfor- mance for LF without or with added fat and to test the hypothesis that increasing LF with added fat would stimulate milk production without depressing milk fat percentage if NFC was decreased. A diet containing a soybean lipid byproduct was added in both studies to serve as a control with increased potential for milk fat depression (Jenkins and McGuire, 2006).

Rumensin (R; monensin sodium; Elanco Animal Health, Greenfield, IN) is an antibiotic ionophore that is commonly added to dairy rations to improve feed efficiency. Methanogens and protozoa are not sensitive or can adapt to monensin (Nagaraja et al., 1997). However, even with some adaptation by some bacteria, persistence of bacterial response to monensin via increased propionate concentration, decreased $\mathrm{CH}_{4}$ production, and decreased ammonia concentration probably accounts for its improvement in feed efficiency (Russell and Houlihan, 2003). Because hyperammonia-producing deaminative bacteria are inhibited (Eschenlauer et al., 2002; Russell and Houlihan, 2003), supplementation of sugars in diets containing $R$ could further exacerbate an ammonia limitation.

Although monensin should increase ruminal concentrations of propionate, the main glucose precursor (McGuffey et al., 2001), it is not clear if this response would be maintained with diets containing sugars, which commonly increase ruminal butyrate concentrations (Maiga et al., 1995; Broderick and Radloff, 2004; DeFrain et al., 2006), sometimes at the expense of propionate (Golombeski et al., 2006). Finally, some dairy herds have milk fat depression when high amounts of ruminally available carbohydrate are fed with $R$, particularly when there is supplemental unsaturated fat in the diet; these responses might be transient (Bell et al., 2006), requiring more long-term feeding trials to assess the efficacy of $R$ when combined with supplemental fat and sugar. Also, increasing the grain percentage of the diet promotes accumulation of isomers from biohydrogenation that are responsible for milk fat depression (Jenkins and McGuire, 2006), although the negative aspects associated with increasing starch availability might depend on dietary situations (Bradford and Allen, 2004). Sucrose has been suggested to promote milk fat depression, whereas the flow of trans-10 isomers from fermenters (Ribeiro et al., 2005) or rates of biohydrogenation (Ribeiro et al., 2007) were not affected when incubations were buffered to prevent $\mathrm{pH}$ decline. The objectives for trial 3 were to investigate our hypothesis that increasing supplementation of LF plus urea concomitant with decreasing NFC concentration to maintain a similar concentration of rumen-degraded NSC would maintain or improve digestibility, stimulate DMI, and increase milk production and increase or 
Table 1. Ingredient composition of diets (trial 1)

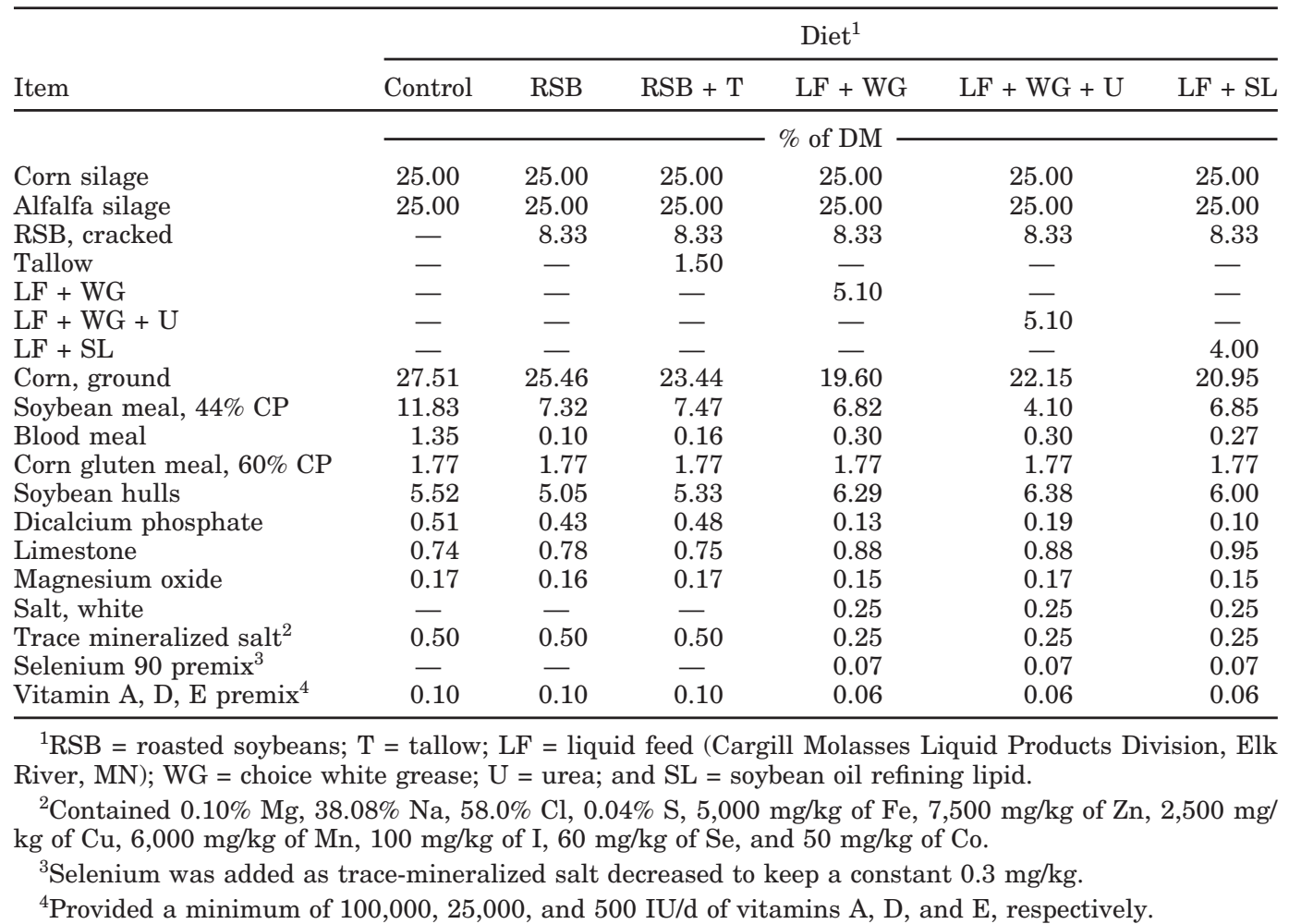

maintain milk fat yield even when $R$ was added to the diet.

\section{MATERIALS AND METHODS}

\section{Trial 1}

Sixty cows were fed a common diet formulated for fresh cows for wk 2 and 3 of lactation. Then, cows ( $\mathrm{n}=$ 24 primiparous and 36 multiparous) were blocked by parity, calving date, and milk production (average of wk 2 and 3). Within block, cows were randomly assigned to the 6 dietary treatments from wk 4 through 19 of lactation. All cows were individually housed in a tiestall barn on bedded mats.

The diets had an equal mix of corn silage and alfalfa silage that comprised $50 \%$ of the diet DM (Table 1). Roasted soybeans (RSB) were added to replace soybean meal and blood meal to provide a source of fat while maintaining approximately similar RUP concentrations. Tallow (T) was added to diets to provide more fat. Finally, an extra increment of fat was provided in the form of LF to be near maximum recommended limits. All diets were balanced to be comparable in minerals and vitamins. The LF contained cane molasses, corn steep liquor, and suspension agents. All LF products for trials 1 and 2 were provided by Cargill Molasses Liquid Products Division (Elk River, MN), which was subsequently sold to Westway Trading Corporation (New Orleans, LA). The animal fat was choice white grease (WG), and this LF product containing WG was marketed as Synergy 200 (Westway). Urea (U) and a small amount of ammonium salts provided NPN (Synergy 20/20). In the last diet, the WG was replaced with neutralized soap stock (soybean oil refining lipid, SL). On a DM basis, the LF + WG, LF + WG + U, and LF + SL products had approximately $30.8,30.3$, and $33.3 \%$ crude fat; $33.5,31.2$, and $16.7 \%$ sugars; and 6.2, 30.3, and $6.7 \% \mathrm{CP}$, respectively. Using a procedure described by Sukhija and Palmquist (1988), the 16:0, 16:1, 18:0, 18:1 trans, $18: 1 \mathrm{cis}, 18: 2 \mathrm{n}-6$, and 18:3n-3 concentrations were $17.4,2.2,11.0,6.2,37.5,13.1$, and $1.0 \mathrm{~g} / 100 \mathrm{~g}$ of fatty acids (FA) from the WG; 13.6, 0.2, 4.1, 0.3, 14.5, 56.2 , and $7.9 \mathrm{~g} / 100 \mathrm{~g}$ from SL; and 33.0, 3.8, 12.8, 3.5, $40.7,7.9$, and $0.6 \mathrm{~g} / 100 \mathrm{~g}$ from the tallow, respectively. The concentrations of FA in tallow were comparable to our previous source (Pantoja et al., 1996). The RSB were not analyzed directly, but based on FA concentrations of the RSB diet (data not shown), the fatty acid profile was typical for RSB. All LF were blended into a separate concentrate mix for each diet in trial 1.

A TMR was mixed for each diet, and daily diets were delivered in barrels, which were weighed and calibrated for $10 \%$ refusal, with feed kept in bunks at all times. Forages, grain mixtures, and TMR were sampled once 
per week per diet and composited monthly for analyses of nutrient composition. Weekly samples were used to adjust TMR for changes in DM percentages of feeds. Cows were milked twice per day, with milk samples collected from 4 consecutive milkings each week. Milk samples were sent to DHI (Columbus, $\mathrm{OH}$ ) for analyses of fat and CP using infrared spectroscopy. Cows were weighed weekly. Using a 1 to 5 scale (NRC, 2001), BCS was evaluated by 2 separate persons at the beginning of the standardization period, the start of the treatment period, and every 4 wk thereafter.

Monthly TMR were subsampled, dried at $55^{\circ} \mathrm{C}$, and ground. Samples were analyzed for NDF with preextraction with hot ethanol and amylase addition (Van Soest et al., 1991), ADF, acid detergent lignin, and Kjeldahl $\mathrm{N}$ by AOAC (1990). We did not correct NDF or ADF for ash. Fatty acids were determined by GLC (Sukhija and Palmquist, 1988), and macrominerals were determined by inductively coupled plasma emission spectroscopy from the Ohio State University STAR lab (Wooster, $\mathrm{OH}$ ). The NDF and $\mathrm{ADF}$ residues were further analyzed for Kjeldahl N concentration. All nutrient analyses were weighted for the number of cows on those respective diets per month and, using monthly composites, for the entire experiment. The $\mathrm{NE}_{\mathrm{L}}$ concentration was estimated using chemical analyses according to the equation of Weiss (1993) and scaled to $3 \times$ maintenance (NRC, 1989).

Milk samples were weighted for individual milk volumes for a weekly average. Energy-corrected milk was calculated based on a $3.5 \%$ fat and $3.2 \%$ protein basis (Tyrrell and Reid, 1965) and $\mathrm{NE}_{\mathrm{L}}$ output in milk was calculated (NRC, 2001) using standard equations. Statistical analyses were performed using Proc Mixed of SAS (SAS Institute, Cary, NC) with a randomized complete block design, with block as a random variable and repeated measures within cow using models described by Reveneau et al. (2005). In all cases, the treatment $\times$ time interaction was judged not to be significant $(P$ $>0.20$ ), so main effect means were compared using an $F$-test-protected LSD.

Six cows were used in a $6 \times 6$ Latin square design with 6 periods of $3 \mathrm{wk}$, with the last week for sampling. Cows were bolus-dosed with a gelatin capsule containing $5 \mathrm{~g}$ of $\mathrm{Cr}_{2} \mathrm{O}_{3}$ twice daily $(10 \mathrm{~g} / \mathrm{d}) 5 \mathrm{~d}$ before collection and during the 4-d collection period. Fecal samples were taken before $\mathrm{Cr}_{2} \mathrm{O}_{3}$ dosage (for background $\mathrm{Cr}$ correction) and at 8 times staggered over the collection period. Fecal samples were composited for analysis of $\mathrm{Cr}$ concentration (Williams et al., 1962), N by the Kjeldahl method, and NDF as described previously. The TMR and refusal samples were taken every day during the 4-d sample collection period for the same chemical analyses. The data were analyzed using Proc
Mixed of SAS, with period and treatment as fixed effects and cow as a random effect. In all cases, treatment differences were based on a $P \leq 0.10$ to protect against Type II error (Berndtson, 1991), and least-significant difference was used to separate treatment means at the same treatment $P$-value reported.

\section{Trial 2}

Sixty cows (30 primiparous and 30 multiparous) were fed a common diet formulated for fresh cows for wk 2 and 3 of lactation and then blocked and assigned to 1 of the treatment diets from wk 4 to 19 of lactation as described for trial 1 . The treatments included a control diet that contained no supplemental fat or LF (Table 2). A second diet contained LF without any added fat. The same product containing LF plus WG as in trial 1 was fed at a low, medium, or high inclusion rate, with the medium amount being at a comparable amount of $\mathrm{LF}$ as the diets containing $\mathrm{LF}$ without fat or LF + SL. Diets were mixed and fed daily as in trial 1 with the exception that the LF were weighed daily for each individual batch of feed. To accomplish this, a bucket was tared for residual LF that remained from the previous weighing (the tare was adjusted for cold weather). The LF was slowly poured over the TMR while mixing and with care to avoid pouring on the ribbon auger or internal side of the mixer wagon. All lactation measurements and feed analyses were taken as described for trial 1.

All statistics were performed as in trial 1 for a randomized complete block design with repeated measures except for treatment mean comparisons. Because treatment $\times$ time interactions were not significant $(P>0.20)$, main effect means were compared with preplanned contrasts. The contrasts were 1) control vs. LF without added fat; 2 ) the LF diet without fat vs. the average of $\mathrm{LF}+\mathrm{WG}$ and $\mathrm{LF}+\mathrm{SL}$ at the medium feeding rates; the 3) linear and 4) quadratic responses in the control, $\mathrm{LF}+\mathrm{WG}$ (low), $\mathrm{LF}+\mathrm{WG}$ (medium), and $\mathrm{LF}+\mathrm{WG}$ (high) diets; and 5) the medium rate of $\mathrm{LF}+\mathrm{WG}$ vs. $\mathrm{LF}+\mathrm{SL}$.

\section{Trial 3}

Diets were formulated to contain $21.0 \%$ forage NDF based on chopped alfalfa hay and corn silage (not kernel processed; Table 3). Whole cottonseed was added as a source of physically effective $\mathrm{NDF}$ and $\mathrm{NE}_{\mathrm{L}}$. However, it also would provide linoleic acid, which would be biohydrogenated in the rumen. In contrast with trials 1 and 2, the LF used in trial 3 was provided by Quality Liquid Feeds (Dodgeville, WI). The LF was composed of cane molasses, corn steep liquor, and other ingredi- 
Table 2. Ingredient composition of diets containing liquid feed supplements (trial 2)

\begin{tabular}{|c|c|c|c|c|c|c|}
\hline \multirow[b]{3}{*}{ Item } & \multicolumn{6}{|c|}{$\operatorname{Diet}^{1}$} \\
\hline & \multirow[b]{2}{*}{ Control } & \multirow{2}{*}{$\frac{\mathrm{LF}}{\mathrm{Med}}$} & \multicolumn{3}{|c|}{ LF + white grease } & \multirow{2}{*}{$\frac{L F+S L}{M e d}$} \\
\hline & & & Low & Med & High & \\
\hline Corn silage & 25.00 & 25.00 & 25.00 & 25.00 & 25.00 & 25.00 \\
\hline Alfalfal silage & 25.00 & 25.00 & 25.00 & 25.00 & 25.00 & 25.00 \\
\hline Corn, ground & 26.86 & 24.01 & 24.55 & 22.29 & 20.03 & 23.10 \\
\hline Soybean meal, $44 \% \mathrm{CP}$ & 8.75 & 8.38 & 8.75 & 8.62 & 8.46 & 8.65 \\
\hline Blood meal & 1.51 & 1.52 & 1.47 & 1.50 & 1.54 & 1.52 \\
\hline Corn gluten meal, $60 \% \mathrm{CP}$ & 2.88 & 2.97 & 2.92 & 2.97 & 3.03 & 2.97 \\
\hline Soybean hulls & 7.62 & 7.62 & 7.62 & 7.62 & 7.62 & 7.62 \\
\hline Dicalcium phosphate & 0.75 & 0.35 & 0.55 & 0.38 & 0.20 & 0.47 \\
\hline LF without fat & - & 3.38 & - & - & - & - \\
\hline $\mathrm{LF}+\mathrm{WG}$ & - & - & 2.46 & 4.92 & 7.38 & - \\
\hline $\mathrm{LF}+\mathrm{SL}$ & - & - & - & - & - & 3.92 \\
\hline Limestone & 0.73 & 0.92 & 0.81 & 0.89 & 0.98 & 0.88 \\
\hline Magnesium oxide & 0.24 & 0.23 & 0.23 & 0.22 & 0.21 & 0.23 \\
\hline Salt, white & - & 0.12 & 0.08 & 0.11 & 0.13 & 0.13 \\
\hline Trace mineralized salt ${ }^{2}$ & 0.56 & 0.40 & 0.44 & 0.36 & 0.29 & 0.41 \\
\hline Selenium 90 premix & 0.01 & 0.04 & 0.04 & 0.06 & 0.09 & 0.04 \\
\hline Vitamin premix ${ }^{3}$ & 0.10 & 0.06 & 0.08 & 0.06 & 0.04 & 0.06 \\
\hline
\end{tabular}

${ }^{1}$ Liquid feed (LF; Cargill Molasses Liquid Products Division, Elk River, MN) was added without fat or with fat at low, medium (Med), and high inclusion rates on a LF basis; the LF diet without fat had the same LF as the medium feeding rates of LF + choice white grease (WG) or LF + soybean oil refining lipid (SL).

${ }^{2}$ Contained $0.10 \% \mathrm{Mg}, 38.08 \% \mathrm{Na}, 58.0 \% \mathrm{Cl}, 0.04 \% \mathrm{~S}, 5,000 \mathrm{mg} / \mathrm{kg}$ of $\mathrm{Fe}, 7,500 \mathrm{mg} / \mathrm{kg}$ of Zn, 2,500 mg/ $\mathrm{kg}$ of $\mathrm{Cu}, 6,000 \mathrm{mg} / \mathrm{kg}$ of $\mathrm{Mn}, 100 \mathrm{mg} / \mathrm{kg}$ of I, $60 \mathrm{mg} / \mathrm{kg}$ of Se, and $50 \mathrm{mg} / \mathrm{kg}$ of Co.

${ }^{3}$ Provided a minimum of $100,000,25,000$, and $500 \mathrm{IU} / \mathrm{d}$ of vitamins A, D, and E, respectively.

Table 3. Ingredient composition of diets containing different concentrations of NSC without or with Rumen$\sin (\text { trial } 3)^{1}$

\begin{tabular}{|c|c|c|c|c|c|}
\hline \multirow[b]{2}{*}{ Ingredient } & \multicolumn{2}{|c|}{$40 \% \mathrm{NFC}$} & \multicolumn{3}{|c|}{$37 \%$ NFC } \\
\hline & Control & $3.25 \% \mathrm{LF}$ & $3.25 \% \mathrm{LF}$ & $6.5 \% \mathrm{LF}$ & $6.5 \% \mathrm{LF}+\mathrm{R}$ \\
\hline Corn silage & 30.00 & 30.00 & 30.00 & 30.00 & 30.00 \\
\hline Alfalfa hay, chopped & 15.00 & 15.00 & 15.00 & 15.00 & 15.00 \\
\hline Whole cottonseed & 8.00 & 8.00 & 8.00 & 8.00 & 8.00 \\
\hline Liquid feed & 0 & 3.25 & 3.25 & 6.50 & 6.50 \\
\hline Corn, ground & 26.40 & 23.37 & 17.97 & 16.00 & 15.99 \\
\hline Soybean hulls & 5.52 & 5.66 & 11.66 & 10.38 & 10.38 \\
\hline Dry distillers grains plus solubles & 4.00 & 4.00 & 4.00 & 4.00 & 4.00 \\
\hline Blood meal, ring dried & 0.80 & 0.80 & 0.80 & 0.80 & 0.80 \\
\hline Soybean meal, expeller & 4.00 & 4.00 & 4.00 & 4.00 & 4.00 \\
\hline Soybean meal, solvent, $48 \% \mathrm{CP}$ & 4.00 & 4.00 & 3.40 & 3.40 & 3.40 \\
\hline Urea & 0.26 & - & - & - & - \\
\hline Dicalcium phosphate & 0.30 & 0.30 & 0.30 & 0.30 & 0.30 \\
\hline Limestone & 0.90 & 0.80 & 0.80 & 0.80 & 0.80 \\
\hline Magnesium oxide & 0.12 & 0.12 & 0.12 & 0.12 & 0.12 \\
\hline Potassium chloride & 0.07 & 0.07 & 0.07 & 0.07 & 0.07 \\
\hline Trace-mineralized salt ${ }^{2}$ & 0.50 & 0.50 & 0.50 & 0.50 & 0.50 \\
\hline Vitamin premix ${ }^{3}$ & 0.13 & 0.13 & 0.13 & 0.13 & 0.13 \\
\hline Rumensin premix ${ }^{4}$ & - & - & - & - & 0.007 \\
\hline
\end{tabular}

${ }^{1} \mathrm{LF}=$ liquid feed (Quality Liquid Feeds, Dodgeville, WI), and R = Rumensin (Elanco Animal Health, Greenfield, IN).

${ }^{2}$ Contained $0.10,38.0,58.0$, and $0.04 \% \mathrm{Mg}, \mathrm{Na}, \mathrm{Cl}$, and $\mathrm{S} ; 5,000,7,500,2,500,6,000,100,60$, and $50 \mathrm{mg} /$ $\mathrm{kg}$ of $\mathrm{Fe}, \mathrm{Zn}, \mathrm{Cu}, \mathrm{Mn}, \mathrm{I}$, Se, and Co, respectively.

${ }^{3}$ Approximately 136,000, 34,000, and 600 IU per cow per day.

${ }^{4}$ Provided $11.5 \mathrm{~g}$ of monensin per $909 \mathrm{~kg}$ of $\mathrm{DM}$ of the total diet. 
ents but in different combinations than the LF used in trials 1 and 2. This product was marketed as TMR 20 (Quality Liquid Feeds) and was blended separately with the rest of the ingredients, as in trial 2. Dry ground corn was substituted by LF and soybean hulls to manipulate NFC concentration (calculated using software from NRC, 2001). The LF feeding rates were based on the assumption of optimum feeding rates of about $2.4 \%$ added sugar, with maximum values of $3.4 \%$ added sugar (Broderick and Radloff, 2004). Based on measured analyses of $53 \%$ sugars in the LF, this optimum and maximum would be 4.5 and $6.4 \%$ LF. Therefore, we formulated $\mathrm{LF}$ rates to be 3.25 and $6.50 \%$.

We assumed $75 \%$ NSC and an apparent ruminal NSC digestibility of $52.3 \%$ (Firkins et al., 2001) for ground corn. The measured 53\% sugars (Dairy One, Ithaca, $\mathrm{NY}$ ) in the product were assumed to be $100 \%$ digestible. Soybean hulls were assumed to contain $21.8 \%$ NFC (NRC, 2001), with approximately 14\% NSC (starch and sugar); because NSC digestibility was comparable when soyhulls replaced ground corn (Mansfield and Stern, 1994), we assumed an apparent digestibility of 55\% of the soyhull NSC. We know of no reliable data to estimate apparent ruminal digestibility of NSC in corn silage, but the mean coefficient in diets with high-moisture corn was $87 \%$ (Firkins et al., 2001). Starch should be lower than NFC in corn silage (Ferreira and Mertens, 2005). Without actual data on the corn silage used, other than an average of $37.6 \% \mathrm{NFC}$, we assumed that this NFC was completely starch and sugars but compensated for this overestimation with a likely underestimated apparent ruminal NSC digestibility of $60 \%$. Using these values, the diets were predicted to have apparent rumen-digestible NSC concentrations of 16.9, $17.5,16.0,16.9$, and $16.9 \%$ of dietary $\mathrm{DM}$ in the $40 \%$ $\mathrm{NFC}$ control, $40 \% \mathrm{NFC}+3.25 \% \mathrm{LF}, 37 \% \mathrm{NFC}+3.25 \%$ $\mathrm{LF}, 37 \% \mathrm{NFC}+6.5 \% \mathrm{LF}$, and $37 \% \mathrm{NFC}+6.5 \% \mathrm{LF}+$ $\mathrm{R}$ diets, respectively. Even if the actual values deviated, differences among treatments should be comparable.

A mix of protein supplements was added to meet predicted NRC (2001) requirements for RUP for dairy cows producing $40.9 \mathrm{~kg} / \mathrm{d}$ of milk with a predicted DMI of $25.6 \mathrm{~kg} / \mathrm{d}$. To prevent a potential limitation of ruminal ammonia, urea was added to maintain at least an $8.0 \%$ safety factor for RDP supply relative to predicted RDP requirements. Rumensin (11.5 g of monensin $/ 909 \mathrm{~kg}$ of DM) was added to be slightly greater than the manufacturer's (Elanco Animal Health) lowest recommended inclusion rate $(11 \mathrm{~g} / 909 \mathrm{~kg}$ of DM).

Starting on wk 9 of lactation, 40 multiparous and 20 primiparous Holstein cows were fed the control diet for $2 \mathrm{wk}$ for standardization and covariate adjustment. Then, cows were blocked by parity, date of calving, and milk production (average from the 2-wk standardiza- tion period) and randomly assigned to either stay on that diet or be switched to one of the other 4 diets for 12 wk. The cows were all administered Posilac (Monsanto, St. Louis, MO) commencing on wk 9 of lactation and administered every 2 wk thereafter. All diets were mixed daily and fed for $10 \%$ orts. Monthly composite samples of TMR, forages, cottonseed, and grain mixes were analyzed for nutrients using standard methods at Dairy One (Ithaca, NY). All analyses are comparable with previous descriptions except that NDF analysis used pretreatment with acetone and incubation with amylase plus sulfite; fat was analyzed by ether extract (AOAC, 1990); and water-soluble monosaccharides (Hall et al., 1999) were preextracted before analysis for starch using gelatinization with an autoclave, hydrolysis with glucoamylase, and analysis by glucose oxidase with standardization against dextrose $(\times 0.9)$. All animal handling, data collection, and data compilation were done as described previously, with the exception that BCS was monitored every $3 \mathrm{wk}$ during the last 12 wk of the experiment.

Five cows ( $\mathrm{n}=2$ rumen cannulated) were used in a $5 \times 5$ Latin square for a digestibility experiment as described for trial 1 with the exception that periods were $4 \mathrm{wk}$, Posilac was administered every 2 wk during the trial, and pellets containing $\mathrm{Cr}_{2} \mathrm{O}_{3}(5 \%)$ and soybean hulls $(95 \%)$ were dosed into the rumen for the rumencannulated cows. For those 2 cows, ruminal samples were taken by cannulas on $0,3,6$, and $9 \mathrm{~h}$ after feeding. For the other 3 cows, gelatin capsules containing $\mathrm{Cr}_{2} \mathrm{O}_{3}$ were dosed twice daily as described in trial 1 . One rumen sample was taken per period by stomach tube at $3 \mathrm{~h}$ after the morning feeding. The concentrations of VFA were determined using GLC (Harvatine et al., 2002). There was no treatment $\times$ time interaction for VFA for the 2 cows (albeit power was insufficient to test this interaction), and a mean was used along with the single value for the noncannulated cows.

All statistics were performed using Proc Mixed of SAS. For the digestibility trial, cow was modeled as a random effect in the Latin square design. For the production trial, the data were weighted for parity (Reveneau et al., 2005). Evaluation of treatment $\times$ time interactions were modeled with the $\operatorname{ar}(1)$ covariance structures (which consistently had the lowest Bayesian information criterion score). In all cases, treatment differences were based on $P \leq 0.10$ to protect against Type II error (Berndtson, 1991). There were no treatment $x$ time interactions $(P>0.10)$, and least-significant difference was used to separate treatment means at the same treatment $P$-value that is reported in the tables.

\section{RESULTS}

\section{Trial 1}

As expected based on diet formulations, diets were comparable in NDF, ADF, and CP (Table 4). As planned, 
Table 4. Chemical composition of diets containing liquid feeds and different fat sources (trial 1)

\begin{tabular}{lcccccc}
\hline & \multicolumn{7}{c}{ Diet $^{1}$} \\
\cline { 2 - 7 } Item & Control & RSB & RSB + T & LF + WG & LF + WG + U & LF + SL \\
\cline { 2 - 7 } & & & & \% of DM & \\
NDF, \% & 31.3 & 31.1 & 31.2 & 31.0 & 31.7 & 31.8 \\
ADF, \% & 18.8 & 18.5 & 18.2 & 18.6 & 18.7 & 18.7 \\
CP, \% & 17.2 & 17.1 & 17.4 & 16.8 & 16.9 & 17.1 \\
Ash, \% & 6.08 & 6.20 & 6.14 & 6.44 & 6.38 & 6.43 \\
Fatty acids (FA), \% & 2.21 & 3.39 & 4.44 & 4.26 & 4.33 & 42.7 \\
NFC, $\%$ & 44.8 & 43.8 & 42.4 & 43.1 & 42.3 & 42.0 \\
$\mathrm{NE}_{\mathrm{L}}{ }^{3}$ Mcal/kg & 1.67 & 1.72 & 1.76 & 1.74 & 0.74 & 1.74 \\
$\mathrm{Ca} \%$ & 1.01 & 0.87 & 0.88 & 0.88 & 0.41 & 0.46 \\
$\mathrm{P}, \%$ & 0.43 & 0.41 & 0.42 & 0.42 & 1.36 & 1.40 \\
$\mathrm{~K}, \%$ & 1.34 & 1.41 & 1.37 & 1.44 & 0.23 & 0.23 \\
$\mathrm{Mg}, \%$ & 0.22 & 0.22 & 0.23 & 0.23 & \\
\hline
\end{tabular}

${ }^{1} \mathrm{RSB}=$ roasted soybeans; $\mathrm{T}$ = tallow, LF = liquid feed (Cargill Molasses Liquid Products Division, Elk River, $\mathrm{MN}), \mathrm{WG}=$ choice white grease, $\mathrm{U}=$ urea, and $\mathrm{SL}=$ soybean oil refining lipid.

${ }^{2} \mathrm{NFC}=100 \%-[(\mathrm{NDF}-\mathrm{NDICP})+\mathrm{CP}+\mathrm{ash}+(\mathrm{FA}+1)]$, where NDICP is neutral detergent insoluble $\mathrm{CP}$, and $\mathrm{FA}+1$ approximates ether extract (NRC, 2001).

${ }^{3} \mathrm{NE}_{\mathrm{L}}$ is calculated using the method of Weiss (1993) and scaled to $3 \times$ maintenance (NRC, 1989).

adding each increment of fat from RSB, tallow, or WG increased the concentration of $\mathrm{FA}$ and $\mathrm{NE}_{\mathrm{L}}$ proportionately.

Dry matter intake, BW, and milk production were not affected by treatment (Table 5). Compared with the control diet, all diets with the greatest amount of fat (RSB $+\mathrm{T}$ and all $3 \mathrm{LF}$ diets) decreased $(P \leq 0.08)$ milk protein percentage but had no effect on milk protein yield. Compared with the control $(P \leq 0.07)$, adding RSB decreased milk fat percentage, but RSB $+\mathrm{T}$ increased it. Cows fed both of the diets with LF + WG (without or with U) had similar fat percentages, but those fed $\mathrm{LF}+\mathrm{SL}$ tended to have a lower fat percentage compared with $\mathrm{LF}+\mathrm{WG}+\mathrm{U}(P=0.07)$ and $\mathrm{LF}+\mathrm{WG}(P=0.12)$ such that LF + SL was comparable with that from the RSB treatment. Milk fat yield was lower $(P<0.05)$ for cows fed RSB but greater for those fed RSB $+\mathrm{T}$ than any of the LF diets, which were comparable to control. Neither ECM nor $\mathrm{NE}_{\mathrm{L}}$ output in milk was affected by treatment, but efficiencies $\left(\mathrm{ECM} / \mathrm{DMI}\right.$ or $\mathrm{NE}_{\mathrm{L}}$ output

Table 5. Lactation performance and apparent total tract digestibilities by cows fed liquid feeds and different fat sources (trial 1)

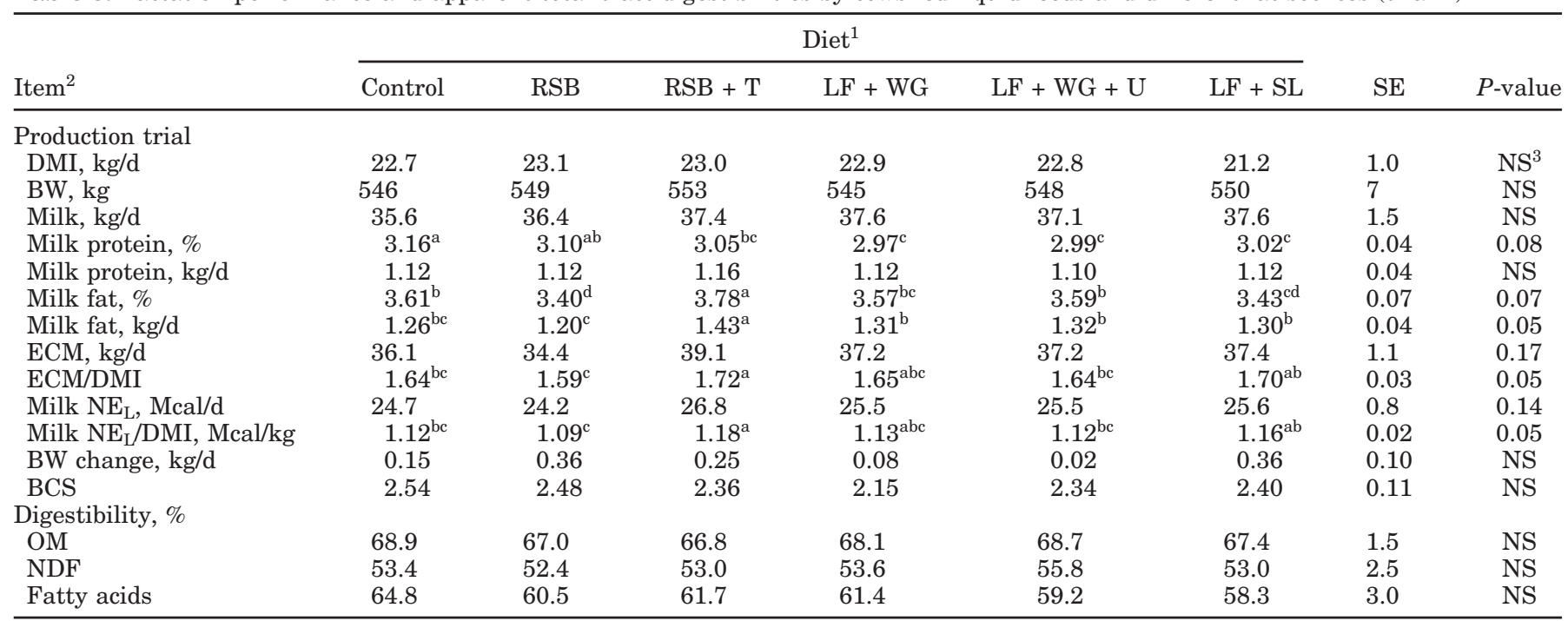

${ }^{\mathrm{a}-\mathrm{c}}$ Means in the same row lacking a common superscript differ according to the $P$-value shown if $P \leq 0.10$.

${ }^{1} \mathrm{RSB}=$ roasted soybeans, $\mathrm{T}=$ tallow, $\mathrm{LF}=$ liquid feed (Cargill Molasses Liquid Products Division, Elk River, MN), WG $=$ choice white grease, $\mathrm{U}=$ urea, and $\mathrm{SL}=$ soybean oil refining lipid.

${ }^{2}$ All production data except BW change are covariate-adjusted means.

${ }^{3} \mathrm{NS}=$ not significant $(P>0.20)$. 
Table 6. Chemical composition of diets containing liquid feed supplements at 3 different feeding rates (trial 2)

\begin{tabular}{|c|c|c|c|c|c|c|}
\hline \multirow[b]{3}{*}{ Item } & \multicolumn{6}{|c|}{$\operatorname{Diet}^{1}$} \\
\hline & \multirow[b]{2}{*}{ Control } & \multirow{2}{*}{$\frac{\mathrm{LF}}{\mathrm{Med}}$} & \multicolumn{3}{|c|}{ LF + choice white grease } & \multirow{2}{*}{$\frac{\mathrm{LF}+\mathrm{SL}}{\mathrm{Med}}$} \\
\hline & & & Low & Med & High & \\
\hline $\mathrm{DM}, \%$ & 51.3 & 49.8 & 50.5 & 51.1 & 49.0 & 50.4 \\
\hline $\mathrm{CP}, \%$ & 17.1 & 17.3 & 17.0 & 16.8 & 16.9 & 17.3 \\
\hline $\mathrm{NDF}, \%$ & 34.1 & 34.4 & 34.6 & 34.5 & 34.3 & 34.1 \\
\hline Fatty acids (FA), \% & 2.58 & 2.59 & 3.12 & 3.79 & 4.42 & 3.46 \\
\hline $\mathrm{NFC}^{2} \%$ & 41.9 & 40.3 & 40.1 & 39.4 & 38.8 & 39.7 \\
\hline $\mathrm{NE}_{\mathrm{L}},{ }^{3} \mathrm{Mcal} / \mathrm{kg}$ & 1.67 & 1.65 & 1.67 & 1.68 & 1.69 & 1.70 \\
\hline $\mathrm{Ca}, \%$ & 1.07 & 0.98 & 0.98 & 1.05 & 0.89 & 1.07 \\
\hline $\mathrm{P}, \%$ & 0.54 & 0.48 & 0.49 & 0.49 & 0.49 & 0.52 \\
\hline $\mathrm{Mg}, \%$ & 0.29 & 0.31 & 0.30 & 0.31 & 0.31 & 0.33 \\
\hline $\mathrm{K}, \%$ & 1.31 & 1.37 & 1.31 & 1.30 & 1.42 & 1.37 \\
\hline
\end{tabular}

\footnotetext{
${ }^{1}$ Liquid feed (LF; Cargill Molasses Liquid Products Division, Elk River, MN) was added without fat or with fat at low, medium (Med), and high inclusion rates on a LF basis; the LF diet without fat had the same LF as the medium feeding rates of LF + choice white grease (WG) or LF + soybean oil refining lipid (SL).

${ }^{2} \mathrm{NFC}=100 \%-[(\mathrm{NDF}-\mathrm{NDICP})+\mathrm{CP}+\mathrm{ash}+(\mathrm{FA}+1)]$, where NDICP is neutral detergent insoluble $\mathrm{CP}$, and FA +1 approximates ether extract (NRC, 2001).

${ }^{3}$ Calculated using the equations of Weiss (1993) and scaled to $3 \times$ maintenance (NRC, 1989).
}

in milk/DMI) were greater $(P<0.05)$ for the RSB $+\mathrm{T}$ treatment compared with control or the RSB treatments. Cows fed $\mathrm{LF}+\mathrm{WG}+\mathrm{U}$ had lower efficiencies than those fed RSB + T, but other treatments were comparable. There were no differences in BW change or BCS or in apparent nutrient digestibilities. Cows in the digestibility experiment averaged $23.7 \mathrm{~kg} / \mathrm{d}$ of DMI (data not shown).

\section{Trial 2}

As in trial 1, all nutrient analyses were comparable among treatments relative to formulation values, and changes in $\mathrm{FA}$ and $\mathrm{NE}_{\mathrm{L}}$ reflected expected rates of fat intake (Table 6). Trial 2 had a control without LF and a diet containing LF without fat (the second diet). The $\mathrm{LF}$ diet without fat was comparable on an LF basis to the LF diets containing WG (fourth diet) or SL (sixth diet), which are labeled in Table 7 as medium rates. Adding fat to $\mathrm{LF}$ diets increased $(P<0.02) \mathrm{DMI}(\mathrm{LF}$ vs. $\mathrm{LF}+\mathrm{WG}$ contrast), but there was a quadratic response $(P<0.02)$ for the feeding amount of $\mathrm{LF}+\mathrm{WG}$. Milk production increased linearly $(P<0.01)$ with increasing $\mathrm{LF}+\mathrm{WG}$, and the quadratic contrast was $P=0.10$.

Milk protein percentage was not affected by treatment. Compared with control, cows fed LF had greater $(P \leq 0.09)$ milk protein yield. The average milk protein yield from the LF + WG or LF + SL treatments was greater than the LF treatment. Increasing amount of $\mathrm{LF}+\mathrm{WG}$ in the diet increased milk protein yield linearly $(P<0.01)$, but the quadratic contrast $(P=0.02)$ indicates a plateau in the response.
Milk fat percentage was greater $(P<0.04)$ for cows fed LF vs. the average of the medium amount of LF + WG or LF + SL, but milk fat yield was similar between those treatments. Both milk fat percentage and yield were markedly lower $(P<0.01)$ for cows fed LF + SL than the medium amount of $\mathrm{LF}+\mathrm{WG}$. Increasing the amount of LF + WG increased milk fat yield the most for the medium feeding rate (the linear and quadratic contrasts were $P<0.01$ and $P<0.10$, respectively).

The yields of both ECM and $\mathrm{NE}_{\mathrm{L}}$ output in milk were greater $(P<0.05)$ for the average of the medium amount of LF + WG plus LF + SL compared with LF, but, as with protein and fat yields, there were both linear and quadratic responses $(P \leq 0.07)$ with increasing amount of LF + WG. Because of a lower DMI, the ECM/DMI was increased for the high feeding amount of $\mathrm{LF}+\mathrm{WG}$ $(P<0.05$ linear increase $)$. The $\mathrm{NE}_{\mathrm{L}}$ output in milk and its efficiency ratio followed similar trends as for ECM or ECM/DMI. Because of numerically greater DMI and lower ECM, the ECM/DMI ratio was lower $(P=0.08)$ for $\mathrm{LF}+\mathrm{SL}$ than for the medium amount of $\mathrm{LF}+\mathrm{WG}$. The LF diet had a greater BW and BW change than the control $(P<0.06)$ and was greater $(P<0.01)$ for BW or tended to be greater $(P=0.13)$ for $\mathrm{BW}$ change than for the average of the $\mathrm{LF}+\mathrm{WG}$ diets.

\section{Trial 3}

The dietary CP ranged from 17.0 to $17.5 \%$ (Table 8). Forage and cottonseed NDF averaged 19.7 and 4.6\%, respectively. The NFC was uniformly about 1 percent- 
Table 7. Lactation performance by dairy cows fed diets containing liquid feed supplements at 3 different feeding rates (trial 2$)^{1}$

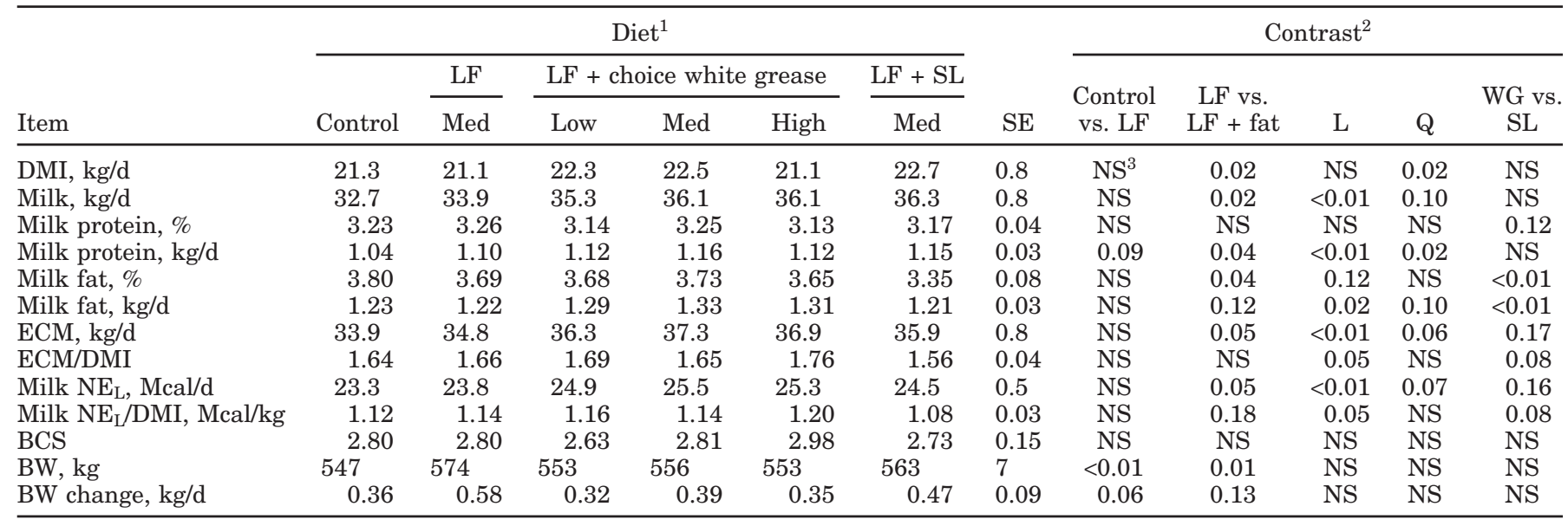

${ }^{1}$ Liquid feed (LF; Cargill Molasses Liquid Products Division, Elk River, MN) was added without fat or with fat at low, medium (Med), and high inclusion rates on an LF basis; the LF diet without fat had the same LF as the medium feeding rates of LF + choice white grease (WG) or LF + soybean oil refining lipid (SL).

${ }^{2} P$-values for contrasts are shown for: 1 ) control vs. $L F$ without added fat; 2 ) the LF diet without fat vs. the average of LF $+\mathrm{WG}$ and LF + SL at the medium (Med) feeding rates; the linear 3) and quadratic 4) responses in the control, LF + WG (Low), LF + WG (Med), and LF + WG (High) diets; and 5) the medium rate of LF + WG vs. LF + SL.

${ }^{3} \mathrm{NS}=$ not significant $(P>0.20)$.

age unit higher than formulated values, but this is likely because the NDF procedure uses sulfite, whereas NDICP does not. Consequently, underestimation of protein-free NDF would subsequently overestimate NFC, verifying our diets to be on target with formulations. The NSC was about 10 percentage units lower than NFC because of soluble fiber from legumes (alfalfa and soybean hulls) and from fermentation acids in corn silage. Of the NSC component, LF substitution for corn grain increased sugar and decreased starch concentrations comparable to treatment design. Other nutrient concentrations were comparable with formulations. We verified by commercial laboratory testing through Elanco Animal Health that our actual measured con-

Table 8. Chemical composition of diets containing different concentrations of NSC without or with Rumensin $($ trial 3)

\begin{tabular}{|c|c|c|c|c|c|}
\hline \multirow[b]{2}{*}{ Composition $^{2}$} & \multicolumn{2}{|c|}{$40 \% \mathrm{NFC}$} & \multicolumn{3}{|c|}{$37 \% \mathrm{NFC}$} \\
\hline & Control & $3.25 \% \mathrm{LF}$ & $3.25 \% \mathrm{LF}$ & $6.5 \% \mathrm{LF}$ & $6.5 \% \mathrm{LF}+\mathrm{R}$ \\
\hline $\mathrm{DM}, \%$ & 63.0 & 62.7 & 63.8 & 64.3 & 64.3 \\
\hline $\mathrm{OM}, \%$ & 93.7 & 93.2 & 93.0 & 92.9 & 92.6 \\
\hline $\mathrm{CP}, \%$ & 17.5 & 17.0 & 17.0 & 17.4 & 17.3 \\
\hline NDF, \% & 32.6 & 32.9 & 35.7 & 35.5 & 35.5 \\
\hline NDICP, \% & 2.7 & 2.1 & 2.9 & 2.9 & 2.9 \\
\hline Forage NDF, \% & 19.7 & 19.7 & 19.7 & 19.7 & 19.7 \\
\hline Cottonseed NDF, \% & 4.6 & 4.6 & 4.6 & 4.6 & 4.6 \\
\hline NFC, \% & 41.1 & 40.3 & 38.3 & 37.9 & 37.7 \\
\hline NSC, $\%$ & 31.5 & 30.1 & 27.5 & 26.3 & 27.8 \\
\hline Starch, \% & 27.4 & 23.9 & 21.0 & 18.2 & 19.0 \\
\hline Sugars, \% & 4.1 & 6.1 & 6.4 & 8.1 & 8.9 \\
\hline Fat, $\%$ & 5.3 & 5.1 & 4.9 & 5.0 & 5.0 \\
\hline $\mathrm{NE}_{\mathrm{L}}, \mathrm{Mcal} / \mathrm{kg}$ & 1.61 & 1.58 & 1.56 & 1.56 & 1.56 \\
\hline $\mathrm{Ca}, \%$ & 0.89 & 0.86 & 0.91 & 0.94 & 0.93 \\
\hline $\mathrm{P}, \%$ & 0.41 & 0.42 & 0.41 & 0.42 & 0.42 \\
\hline $\mathrm{Mg}, \%$ & 0.28 & 0.29 & 0.30 & 0.31 & 0.30 \\
\hline $\mathrm{K}, \%$ & 1.3 & 1.4 & 1.4 & 1.4 & 1.4 \\
\hline
\end{tabular}

${ }^{1} \mathrm{LF}=$ liquid feed (Quality Liquid Feeds, Dodgeville, WI), and R = Rumensin (Elanco Animal Health, Greenfield, IN).

${ }^{2} \mathrm{All}$ were on a $105^{\circ} \mathrm{C} \mathrm{DM}$ basis except for DM (\% on an as-is basis); NDICP = neutral detergent insoluble $\mathrm{CP} ; \mathrm{NFC}=[\mathrm{OM}-(\mathrm{NDF}-\mathrm{NDICP})-\mathrm{CP}-$ crude fat $]$, and $\mathrm{NSC}=$ chemically measured starch plus sugars; $\mathrm{NE}_{\mathrm{L}}$ was estimated (NRC, 2001). 
Table 9. Lactation performance by dairy cattle fed diets containing different concentrations of NSC without or with Rumensin (trial 3$)^{1}$

\begin{tabular}{|c|c|c|c|c|c|c|c|}
\hline \multirow[b]{2}{*}{ Item } & \multicolumn{2}{|c|}{$40 \% \mathrm{NFC}$} & \multicolumn{3}{|c|}{$37 \%$ NFC } & \multirow[b]{2}{*}{ SE } & \multirow[b]{2}{*}{$P$-value } \\
\hline & Control & $3.25 \% \mathrm{LF}$ & $3.25 \% \mathrm{LF}$ & $6.5 \% \mathrm{LF}$ & $6.5 \% \mathrm{LF}+\mathrm{R}$ & & \\
\hline DMI, kg/d & $23.9^{b}$ & $23.9^{b}$ & $25.2^{\mathrm{ab}}$ & $25.9^{\mathrm{a}}$ & $24.5^{\mathrm{b}}$ & 0.7 & 0.08 \\
\hline Milk, kg/d & 39.7 & 39.9 & 41.6 & 40.7 & 40.3 & 0.9 & $\mathrm{NS}^{2}$ \\
\hline Protein, \% & $2.93^{\mathrm{a}}$ & $2.82^{\mathrm{b}}$ & $2.85^{\mathrm{b}}$ & $2.85^{\mathrm{b}}$ & $2.83^{\mathrm{b}}$ & 0.02 & 0.01 \\
\hline Protein kg/d & 1.16 & 1.13 & 1.18 & 1.16 & 1.14 & 0.03 & NS \\
\hline MUN, mg/dL & $12.3^{\mathrm{bc}}$ & $11.8^{\mathrm{c}}$ & $12.8^{\mathrm{b}}$ & $13.8^{\mathrm{a}}$ & $13.5^{\mathrm{a}}$ & 0.5 & 0.08 \\
\hline Fat, \% & 3.31 & 3.42 & 3.34 & 3.29 & 3.31 & 0.07 & $\mathrm{NS}$ \\
\hline Fat, kg/d & $1.31^{\mathrm{b}}$ & $1.28^{\mathrm{b}}$ & $1.39^{\mathrm{a}}$ & $1.33^{\mathrm{b}}$ & $1.32^{\mathrm{b}}$ & 0.03 & 0.08 \\
\hline $\mathrm{ECM}, \mathrm{kg} / \mathrm{d}$ & $37.9^{\mathrm{b}}$ & $37.3^{\mathrm{b}}$ & $39.7^{\mathrm{a}}$ & $38.5^{\mathrm{ab}}$ & $38.0^{\mathrm{ab}}$ & 0.8 & 0.08 \\
\hline ECM/DMI & 1.61 & 1.56 & 1.64 & 1.57 & 1.58 & 0.05 & NS \\
\hline Milk NE $\mathrm{N}_{\mathrm{L}}, \mathrm{Mcal} / \mathrm{d}$ & $26.2^{\mathrm{b}}$ & $25.7^{\mathrm{b}}$ & $27.4^{\mathrm{a}}$ & $26.5^{\mathrm{ab}}$ & $26.2^{\mathrm{b}}$ & 0.5 & 0.09 \\
\hline Milk $\mathrm{NE}_{\mathrm{L}} / \mathrm{DMI}, \mathrm{Mcal} / \mathrm{kg}$ & 1.11 & 1.07 & 1.13 & 1.08 & 1.09 & 0.04 & NS \\
\hline $\mathrm{BW}, \mathrm{kg}$ & 616 & 605 & 607 & 619 & 617 & 5 & $\mathrm{NS}$ \\
\hline BW change, $\mathrm{kg} / \mathrm{d}$ & 0.51 & 0.28 & 0.33 & 0.58 & 0.46 & 0.09 & 0.13 \\
\hline BCS & 2.88 & 2.74 & 2.95 & 2.87 & 2.76 & 0.07 & $\mathrm{NS}$ \\
\hline
\end{tabular}

${ }^{\mathrm{a}-\mathrm{c}}$ Means in the same row lacking a common superscript differ according to the $P$-value shown if $P \leq 0.10$.

${ }^{1} \mathrm{LF}=$ liquid feed (Quality Liquid Feeds, Dodgeville, WI), and R = Rumensin (Elanco Animal Health, Greenfield, IN).

${ }^{2} \mathrm{NS}=$ not significant $(P>0.20)$.

centration of $\mathrm{R}$ was within specifications of expected $\mathrm{R}$ concentration.

Compared with the $40 \%$ NFC control, adding $3.25 \%$ $\mathrm{LF}$ in the $40 \%$ NFC diet did not stimulate DMI, but cows increased $(P<0.08)$ DMI when $6.5 \%$ LF were added to $37 \%$ NFC diets (Table 9). Cows fed the $37 \%$ NFC diet with $3.25 \% \mathrm{LF}$ tended $(P<0.12)$ to have greater DMI than both the control and the $40 \%$ NFC diet with $3.25 \% \mathrm{LF}$. When $\mathrm{R}$ was added to the $6.5 \% \mathrm{LF}$ diet, DMI decreased $(P<0.08)$. Despite the changes in DMI, milk production was not affected by treatment.

Cows fed any of the $4 \mathrm{LF}$ diets had lower $(P<0.01)$ milk protein percentage compared with the control (these are true protein in contrast with CP for trials 1 and 2), but milk protein yield was not affected by treatment. The MUN was greatest $(P \leq 0.08)$ for both of the $6.5 \% \mathrm{LF}$ diets (without or with R). Cows fed the $3.25 \% \mathrm{LF}$ diet with $40 \%$ NFC had a lower MUN than the $3.25 \% \mathrm{LF}$ diet with $37 \% \mathrm{NFC}$.

Milk fat percentage was not affected by treatment, but the greatest $(P \leq 0.08)$ milk fat yield was for cows fed the $3.25 \%$ LF diet containing $37 \%$ NFC. The ECM was greater $(P \leq 0.08)$ when $3.25 \% \mathrm{LF}$ was added to $37 \% \mathrm{NFC}$ diets compared with control or $3.25 \% \mathrm{LF}$ in $40 \%$ NFC diets, and ECM yields for cows fed $6.25 \%$ LF without or with monensin in 37\% NFC diets were intermediate. The $\mathrm{NE}_{\mathrm{L}}$ output in milk followed similar trends $(P \leq 0.09)$ as did ECM except that the difference between the $3.25 \% \mathrm{LF}$ treatment with $37 \% \mathrm{NFC}$ and the $6.5 \% \mathrm{LF}+\mathrm{R}$ treatment exceeded the significance threshold. There were no differences in either measure of efficiency, BW, BW change, or BCS.
Nutrient digestibility and VFA concentrations were not affected by treatment (Table 10). Cows in this experiment averaged $25.7 \mathrm{~kg} / \mathrm{d}$ of DMI (data not shown).

\section{DISCUSSION}

In trial 1 , our objectives were to compare different fat sources suspended in LF and a potential response from urea. Consequently, the LF products were compared with conventional sources of fat and protein (RSB without or with $\mathrm{T}$ ) that were included in their separate concentrate mixes that were added in their respective TMR. In trial 2, our objectives were to differentiate the potential benefits of the LF from the fat carried by the LF, so we added the LF separately and as the last ingredient of the TMR. These 2 trials were completed in 1995 and 1996, respectively. By the time that trial 3 was initiated in 2005, direct LF addition to TMR containing dry hay had become more commonplace on dairy farms, and $R$ was approved for use in lactating dairy cattle. In trial 3 , there was a basal amount of fat from distillers grains and whole cottonseed in all diets, and our objectives were to compare the potential stimulation of DMI by LF and a corresponding increase in ECM that we predicted would follow, even with Rumensin, if we lowered NFC to maintain rumen-degraded carbohydrate.

\section{Trial 1: Different Fat Sources and NPN in LF Added to Concentrates}

Adding more dietary fat generally reduced milk protein percentage (Table 5). The greater milk protein per- 
Table 10. Apparent total tract digestibility and rumen fermentation characteristics in lactating dairy cattle fed diets containing different concentrations of NSC without or with Rumensin (trial 3$)^{1}$

\begin{tabular}{|c|c|c|c|c|c|c|}
\hline \multirow[b]{2}{*}{ Item } & \multicolumn{2}{|c|}{$40 \%$ NFC } & \multicolumn{3}{|c|}{$37 \%$ NFC } & \multirow[b]{2}{*}{ SE } \\
\hline & Control & $3.25 \% \mathrm{LF}$ & $3.25 \% \mathrm{LF}$ & $6.5 \% \mathrm{LF}$ & $6.5 \% \mathrm{LF}+\mathrm{R}$ & \\
\hline OM digestibility, \% & 76.3 & 75.1 & 75.7 & 76.3 & 75.5 & 2.3 \\
\hline NDF digestibility, \% & 52.1 & 44.8 & 49.6 & 51.8 & 41.1 & 5.5 \\
\hline $\mathrm{N}$ digestibility, $\%$ & 70.5 & 65.8 & 67.7 & 67.4 & 68.7 & 2.5 \\
\hline Total VFA, $\mathrm{m} M$ & 106 & 107 & 113 & 110 & 99 & 19 \\
\hline \multicolumn{7}{|c|}{ Individual VFA, mol/100 mol } \\
\hline Acetate & 64.9 & 65.6 & 64.8 & 64.9 & 64.8 & 1.8 \\
\hline Propionate & 21.0 & 20.7 & 20.0 & 20.9 & 21.1 & 1.6 \\
\hline Butyrate & 10.7 & 10.2 & 11.2 & 10.8 & 10.1 & 0.6 \\
\hline Isobutyrate & 0.81 & 0.83 & 0.90 & 0.75 & 0.91 & 0.08 \\
\hline Isovalerate & 1.37 & 1.29 & 1.40 & 1.25 & 1.38 & 0.17 \\
\hline Valerate & 1.38 & 1.39 & 1.71 & 1.31 & 1.63 & 0.21 \\
\hline $\mathrm{BCVFA}^{2}$ & 3.58 & 3.51 & 4.01 & 3.31 & 3.92 & 0.41 \\
\hline Acetate:propionate & 3.20 & 3.25 & 3.36 & 3.13 & 3.17 & 0.32 \\
\hline
\end{tabular}

centage for the RSB $+\mathrm{T}$ treatment might be related to a slightly higher measured CP percentage for that diet (Table 4). Jenkins and McGuire (2006) recently discussed a cumulative understanding of how supplemental fat usually depresses milk protein percentage without changing protein yield. There were no effects from adding urea to the LF + WG diet. Sannes et al. (2002) reported that sucrose decreased the outflow of urinary purine derivatives (a surrogate for estimating microbial protein synthesis) but decreased ruminal $\mathrm{NH}_{3}-\mathrm{N}$ and MUN, so cows fed LF + WG (even without U) appears not to have been limited in $\mathrm{NH}_{3}-\mathrm{N}$ under our circumstances.

Supplemental sources of unsaturated fat can depress fiber digestibility and potentially decrease milk fat percentage, although RSB should have a much more limited response because of the slower release of oil from the seed (Jenkins and McGuire, 2006). However, total tract NDF digestibility was not affected by treatment (Table 5), so the increase in milk fat percentage and yield by providing tallow to RSB or WG in the LF treatments compared with the RSB treatment should be a result of increased intake of supplemental saturated fatty acids. Fatty acid digestibility was not affected by treatment, so increasing saturated fatty acid supply should increase transfer to the milk and dilute the negative effects of absorbed intermediates from biohydrogenation of unsaturated fatty acids on de novo milk fatty acid synthesis (Shingfield et al., 2006). Compared with the RSB treatment, ECM/DMI and $\mathrm{NE}_{\mathrm{L}}$ output in milk/DMI were greater for cows fed RSB $+\mathrm{T}$, although DMI, ECM, and $\mathrm{NE}_{\mathrm{L}}$ output in milk were not affected. The RSB diet tended to have slightly greater predicted $\mathrm{NE}_{\mathrm{L}}$ concentration than RSB $+\mathrm{T}$, which was greater than control (Table 4), but measures of gross feed efficiency did not seem to be closely related to $\mathrm{NE}_{\mathrm{L}}$ concentration.

\section{Trial 2: Source of Fat and Amount of LF Blended in TMR}

Compared with the control, cows fed the LF diet without fat increased milk protein yield, BW, and BW change (Table 7). Even though the NFC concentration was slightly greater (Table 6), the LF might have provided more ruminally available carbohydrate to stimulate propionate production and microbial protein synthesis, which could enhance milk protein production (Jenkins and McGuire, 2006). Increasing insulin concentration could also limit adipose tissue mobilization or enhance lipid uptake, explaining the increased BW change for cows fed LF (Table 7). Increasing insulin concentration associated with increased ruminal carbohydrate digestibility might decrease DMI (Bradford and Allen, 2007), so lack of decrease in DMI might be associated with improved palatability of sugar-containing diets (Murphy et al., 1997).

In the contrast for $\mathrm{LF}+$ fat (the average of the medium amount of $\mathrm{LF}+\mathrm{WG}$ and the $\mathrm{LF}+\mathrm{SL}$ treatments), DMI increased compared with LF alone (Table 7), which was unexpected. Because the dose response for increasing amounts of $\mathrm{LF}+\mathrm{WG}$ (control vs. low, medium, and high LF + WG diets) was quadratic, the greater amount of LF + WG probably decreased DMI through chemostatic regulation mechanisms (Allen, 2000). We calculated the iodine value to be about 135 for the LF containing SL, whereas the iodine value was about 69 for the LF containing WG. Although unsaturated fat in the 
SL would be expected to potentially depress DMI (Allen, 2000 ) through decreasing meal size (Harvatine and Allen, 2006b), again no such effect on DMI was detected until this high feeding rate. The DMI was not stimulated by the LF diet without fat compared with control, so palatability issues associated with LF without fat appear not to explain the responses. A mechanism for stimulation of DMI by adding moderate amounts of fat to the LF is not clear but deserves further study.

Milk production was increased when fat was added to LF diets compared with LF alone (Table 7). There was also a linear $(P<0.01)$ and quadratic $(P=0.10)$ effect of amount of $\mathrm{LF}+\mathrm{WG}$. There was a larger relative increase in milk production from the control compared with the lower feeding amount of LF + WG, followed by a gradual peaking with increasing increments of $\mathrm{LF}+\mathrm{WG}$. There was less symmetry in the quadratic response, which would increase its $P$-value. Consequently, the combination of a significant linear contrast with a strong trend for a quadratic contrast supports a plateau response. Similar responses were detected in yield of milk protein, fat, $\mathrm{ECM}$, and $\mathrm{NE}_{\mathrm{L}}$ output in milk. Thus, in support of generally quadratic results using molasses (without fat) reported by Broderick and Radloff (2004), the medium feeding rate of LF + WG would be considered optimal for milk production under our circumstances.

As explained previously, Maiga et al. (1995) did not see an apparent benefit from sugar-containing supplements with fat at 7.4 to $8.3 \%$ of DM, which approximated our high amount of LF + WG. As we increased the amount of $\mathrm{LF}+\mathrm{WG}$, the NFC decreased from $41.9 \%$ in the control to $38.8 \%$ in the high feeding amount of $\mathrm{LF}+\mathrm{WG}$ (Table 6). Moreover, increasing amount of LF + WG increased milk protein yield while cows increased their consumption of supplemental dietary fat. Perhaps milk protein depression associated with fat feeding was less severe because we only added moderate amounts of fat and provided high-quality RUP sources or because the LF + WG helped to prevent suppressions in DMI that are correlated with milk protein depression from supplemental fat (Wu and Huber, 1994).

Although milk production was maintained when cows were fed the LF + SL diet, milk fat percentage and yield were decreased compared with the medium amount of LF + WG. As explained by Harvatine and Allen (2006a), lipid-induced milk fat depression without depressed DMI should increase BW gain. The BW gain was numerically but not statistically increased with the LF + SL diet compared with the medium amount of LF + WG. We noted similar trends and responses for decreases in other variables, particularly for efficiency of ECM or $\mathrm{NE}_{\mathrm{L}}$ output in milk per unit of DMI, when SL was added to the LF. Although soybean soapstock decreased the rate of NDF degradation in situ (Abel-Caines et al., 1998), we did not detect any differences in kinetics of degradation of NDF from either ground alfalfa or orchardgrass hays (data not shown). Therefore, the results seem to be more likely associated with increased intermediates of biohydrogenation of linoleic acid (which was the major fatty acid in SL) and resultant depression of milk fat percentage that persisted longterm (Shingfield et al., 2006). From our responses in both trials 1 and 2, the usage of SL at these feeding amounts should be considered with respect to potential for milk fat depression.

\section{Trial 3: Response to Amount of LF Blended into TMR Balanced for Rumen-Degraded Carbohydrate and Containing Rumensin}

Compared with the control, the concentration of ruminally degraded NSC was formulated to be the greatest in the $40 \% \mathrm{NFC}$ diet with $3.25 \% \mathrm{LF}$, the lowest in the $37 \%$ NFC diet with $3.25 \% \mathrm{LF}$, and to be intermediate and equivalent to the $6.5 \% \mathrm{LF}$ diets (see earlier discussion). Therefore, we expected that a benefit in enhanced palatability might increase DMI if ruminal carbohydrate availability did not suppress DMI (Allen, 2000). The stimulation of DMI in the $3.25 \%$ LF diets by diluting NFC from 40 to $37 \%$ supports our hypothesis. As in many but not all of the ionophore studies summarized by Ipharraguerre and Clark (2003), adding $\mathrm{R}$ to the $6.5 \% \mathrm{LF}$ diet depressed DMI. Our inclusion rate (which met label requirements for the lowest concentration to improve feed efficiency) was lower than that of some studies that reported depressed DMI (Bell et al., 2006; Odongo et al., 2007), but the decrease in DMI was not positively related to $\mathrm{R}$ feeding rate (Phipps et al., 2000).

There were no significant differences in milk production or milk protein yield, but milk protein percentage was decreased with all diets containing LF compared with the control, but most of this response would be expected to be a result of dilution because protein yield was not affected (Table 9). Milk protein percentage was lower or tended to be lower when LF diets were fed in trials 1 and 2 and could not be differentiated into effects of LF vs. added fat in trial 2. Molasses did not depress milk protein percentage in the study of Broderick and Radloff (2004) but tended to decrease it in the study of Maiga et al. (1995). Generally, milk protein percentage is depressed by several factors (Jenkins and McGuire, 2006), but as discussed subsequently, none of these factors seem relevant for LF feeding. In trial 3, the LF diets had lower concentrations of ground corn (Table 3). Although the greater concentration of starch vs. sugar in the control could be supporting more microbial 
protein synthesis because of more continuous carbohydrate supply and synchronization with RDP than with LF diets, in vivo support for this synchronization response for dairy cattle is equivocal (Firkins et al., 2006), and LF concentrations were balanced to not exceed recommended sugar concentrations (Broderick and Radloff, 2004). Using the procedure of Griswold et al. (2003), the concentration of ruminal peptides in the 2 rumencannulated cows was actually numerically greater when the cows were fed the control treatment than the others, and all $\mathrm{NH}_{3}-\mathrm{N}$ concentrations were $>10 \mathrm{mg} / \mathrm{dL}$ (data not shown). In cows fed $20 \%$ of the diet as various carbohydrate sources, $\mathrm{NH}_{3}-\mathrm{N}$ irreversible loss from the rumen decreased compared with a control; this response was attributed to decreased deamination when the cows were fed glucose and to increased incorporation of $\mathrm{NH}_{3}-\mathrm{N}$ into microbial protein when they were fed starch (Hristov et al., 2005). Molasses and sugars often decrease rumen $\mathrm{NH}_{3}-\mathrm{N}$ and MUN (Sannes et al., 2002), but this response was quadratic in 2 studies (Broderick and Radloff, 2004), and our MUN data do not support any major change in $\mathrm{N}$ metabolism in the rumen. The MUN was greater for the $6.25 \% \mathrm{LF}$ diets, but this response likely was a result of higher CP in the diet formulations with increasing LF, even though the analyses (Table 8) did not detect a difference. An increased propionate concentration and resultant insulin response to increase milk protein percentage (Jenkins and McGuire, 2006) also are not corroborated by our VFA data (Table 10), which were not affected by treatment, or by milk lactose, which ranged only from 4.74 to $4.77 \%$ among treatments (data not shown). Therefore, the decrease in milk protein concentration by LF treatments is likely just a simple dilution response, which seems consistent with typical responses in which milk protein yield was unchanged or increased with increasing milk yield when sugars were supplemented.

Milk fat percentage was not affected by LF in trial 3 (Table 9). Cows in trial 3 were later in lactation and were injected with bST, but long-term administration should not affect milk component concentrations (NRC, 2001). Milk fat percentage in trial 1 decreased with LF + WG compared with the RSB + T diet but not when compared with the control (Table 5), and increasing amount of LF + WG did not affect milk fat percentage in trial 2 (Table 7). These results could be explained, in part, from those diets in trial 1 having greater NFC concentrations than optimal, whereas trial 2 and especially trial 3 evaluated LF when ruminal carbohydrate availability was controlled. However, adding molasses or sucrose to diets comparable or higher in NFC than in our trials (Cherney et al., 2003; Broderick and Radloff, 2004) did not affect milk fat percentage or increase it, and NFC concentration within or among studies had little apparent effect. Also, sucrose addition did not direct the flux of biohydrogenation toward the trans-10 pathway (Ribeiro et al., 2007), so we would not expect sugars to depress milk fat unless the $\mathrm{pH}$ declined significantly. Perhaps the stimulation of DMI by LF helps protect the rumen from conditions that lead to accumulation of FA intermediates from biohydrogenation that promote milk fat depression (Bradford and Allen, 2004).

Although we could not measure $\mathrm{pH}$ in our trial for the noncannulated cows (and there was no difference among treatments for the 2 cannulated cows; data not shown), Broderick and Radloff (2004) noted that $\mathrm{pH}$ or VFA proportions did not respond to increasing dietary concentrations of molasses. Our VFA data (Table 10) also were not affected by diet. As discussed previously, many studies with sucrose or other sugars often increase the molar proportion of butyrate (Maiga et al., 1995; Golombeski et al., 2006). In contrast, butyrate molar percentage did not increase when sucrose was added to diets containing high-moisture corn (Cherney et al., 2003; Broderick and Radloff, 2004). Because highmoisture corn has a very high ruminal NSC digestibility but does not depress ruminal $\mathrm{pH}$ compared with ground dried corn (Firkins et al., 2001), butyrate concentration might only increase when LF promotes lactate production and subsequent conversion to butyrate (Firkins et al., 2006).

When $3.25 \% \mathrm{LF}$ was added to the $37 \%$ NFC diet, milk fat yield was greater compared with any other treatment. This treatment also had greater yields of $\mathrm{ECM}$ and $\mathrm{NE}_{\mathrm{L}}$ output in milk compared with the control or $3.25 \% \mathrm{LF}$ diet with $40 \% \mathrm{NFC}$, whereas both of the $6.25 \%$ LF diets were intermediate (Table 9 ). Thus, most of the response is a result of increases or tendencies for increases in DMI by cows fed LF when the NFC and ruminal carbohydrate availability are moderated by ration formulation (see earlier discussion). Yields of milk fat, $\mathrm{ECM}$, or $\mathrm{NE}_{\mathrm{L}}$ output were relatively proportional to DMI such that there were no differences in ECM/ $\mathrm{DMI}$ or $\mathrm{NE}_{\mathrm{L}}$ output in milk/DMI associated with feeding LF. Although VFA proportions were not changed, increasing the ruminal degradability of carbohydrate by adding $3.25 \% \mathrm{LF}$ in the $40 \% \mathrm{NFC}$ diet should increase the amount of VFA production, thus increasing the potential for DMI suppression with increasing ruminal fermentability of the diet (Allen, 2000; Bradford and Allen, 2007).

We expected a decrease in the acetate:propionate ratio associated with feeding R (McGuffey et al., 2001), but no responses were detected (Table 10). As discussed by Bell et al. (2006), there is some concern about longterm adaptation by ruminal microbes to monensin. However, Odongo et al. (2007) detected a long-term 
decrease in methane production from feeding monensin. In fact, physiological adaptation to $\mathrm{R}$ is more likely than a decrease in sensitivity through genetic mutation (Russell and Houlihan, 2003), so a concomitant ripple through the entire microbial ecosystem would be expected to interact with other dietary factors. For example, shifts in concentrations of FA isomers from feeding supplemental unsaturated fat can take longer for equilibration (Shingfield et al., 2006), so longer term changes in microbial population structure or fermentation pattern could be associated with various factors other than monensin sensitivity.

Adding $\mathrm{R}$ to the $6.25 \% \mathrm{LF}$ diet decreased DMI without affecting $\mathrm{ECM}$ or $\mathrm{NE}_{\mathrm{L}}$ output in milk. Algebraically, the mean of 2 variables will not equal the mean of the ratio of those 2 variables; combined with covariate analysis, there might have been some more extreme values for individual $\mathrm{ECM}$ and $\mathrm{NE}_{\mathrm{L}}$ output in milk or DMI that normalized when the individual efficiency ratios were evaluated statistically. In summaries of ionophore research, monensin typically slightly decreased DMI and slightly increased milk production (Ipharraguerre and Clark, 2003), explaining the general response in improved feed efficiency (McGuffey et al., 2001). In contrast with other responses (Bell et al., 2006 ), adding $\mathrm{R}$ to the $6.25 \% \mathrm{LF}$ diet was not expected to depress milk fat percentage because the ruminal carbohydrate availability was moderated by addition of nonforage NDF and because a major source of unsaturated fat was from whole cottonseed, which decreases trans isomer accumulation compared with processed cottonseeds (Reveneau et al., 2005). Milk fat depression by monensin is associated with increased accumulation of intermediates of biohydrogenation of unsaturated fat (Benchaar et al., 2006), but moderation of the diet fermentability also should help maintain ruminal protozoa populations that incorporate unsaturated fatty acids (Devillard et al., 2006) and bacteria responsible for reducing the trans intermediates of biohydrogenation to stearic acid (Firkins et al., 2006).

There were no differences in any measurements from the digestibility study (Table 10). The DMI ranged from 24.5 to $26.8(\mathrm{SE}=1.5) \mathrm{kg} / \mathrm{d}$ (data not shown). The lack of treatment differences contrasted with changes in DMI in the longer term production trial, documenting the importance of continuous lactation trials to evaluate the true efficacy of treatments. Unfortunately, high variability in fecal output predictions, which are most likely explained by increased error associated with bolus-dosing of $\mathrm{Cr}_{2} \mathrm{O}_{3}$ in this study, decreased the accuracy of the mean values and the sensitivity for treatment comparisons. Modeling cow as a random effect considers the variance of cow in addition to the residual variance, often increasing the $\mathrm{SE}$ without changing power to detect differences (Harvatine et al., 2002). The heterogeneity of cows (cannulated vs. noncannulated) might further increase the among-cow response to treatments, as has been shown for cows fed different fat sources (Harvatine and Allen, 2006a). Despite these limitations, the lack of consistent differences in nutrient digestibility or VFA proportions among treatment means support the likelihood that major responses in lactation performance are associated with responses in DMI.

\section{CONCLUSIONS}

There were no differences in total tract digestibility in trials 1 and 3 . There were no responses to urea addition to LF, perhaps because these LF products had peptides that might have been more limiting for microbial protein synthesis than was $\mathrm{NH}_{3}-\mathrm{N}$. Both trials 1 and 2 demonstrated full efficacy of the WG suspended in $\mathrm{LF}$, and adding LF did not depress milk fat percentage unless the fat source was SL. In trial 1, when LF was blended into the concentrate, there were few differences in lactation performance. However, when combined with WG in trial 2 or when NFC was decreased to maintain ruminal carbohydrate digestibility in trial 3, LF blended with the TMR stimulated DMI, which is the major driver stimulating production of milk fat or ECM. Because these responses to $\mathrm{LF}+\mathrm{WG}$ in trial 2 generally were quadratic and the $3.25 \% \mathrm{LF}$ diet maximized DMI and ECM compared with 6.5\% LF in trial 3 , intermediate feeding rates probably optimize palatability of LF while minimizing potential DMI limitations associated with increasing ruminal fermentability. The LF products used in our trials should be considered as high-quality sources of energy and other nutrients that maintain or improve milk fat production when NFC is moderated and when LF are fed as a separate ingredient in TMR at inclusion rates of approximately $3.25 \%$ (1.7\% sugar, trial 3 ) or $5 \%(1.6 \%$ sugar, trial 2) while potentially offering other advantages in feed bunk management for group-fed cows.

\section{ACKNOWLEDGMENTS}

The authors would like to thank Maurice Eastridge and Normand St-Pierre (The Ohio State University) for their many helpful discussions and Andy Spring, John Lemmermen, and the many student workers at the Waterman Dairy Farm (Columbus, $\mathrm{OH}$ ) for their hard work and attention to experimental protocols during these 3 projects.

\section{REFERENCES}

Abel-Caines, S. F., R. J. Grant, and M. Morrison. 1998. Effect of soybean hulls, soy lecithin, and soapstock mixtures on ruminal 
fermentation and milk composition in dairy cows. J. Dairy Sci. 81:462-470.

Allen, M. S. 2000. Effects of diet on short-term regulation of feed intake by lactating dairy cattle. J. Dairy Sci. 83:1598-1624.

AOAC. 1990. Official Methods of Analysis. 15th ed. AOAC, Arlington, VA.

Bell, J. A., J. M. Griinari, and J. J. Kennelly. 2006. Effect of safflower oil, flaxseed oil, monensin, and vitamin $\mathrm{E}$ on concentration of conjugated linoleic acid in bovine milk fat. J. Dairy Sci. 89:733-748.

Benchaar, C., H. V. Petit, R. Berthiaume, T. D. Whyte, and P. Y. Chouinard. 2006. Effects of addition of essential oils and monensin premix on digestion, ruminal fermentation, milk production, and milk composition in dairy cows. J. Dairy Sci. 89:4352-4364.

Berndtson, W. E. 1991. A simple, rapid and reliable method for selecting or assessing the number of replicates for animal experiments. J. Anim. Sci. 69:67-76.

Bradford, B. J., and M. S. Allen. 2004. Milk fat responses to a change in diet fermentability vary by production level in dairy cattle. J. Dairy Sci. 87:3800-3807.

Bradford, B. J., and M. S. Allen. 2007. Depression in feed intake by a highly fermentable diet is related to plasma insulin concentration and insulin response to glucose infusion. J. Dairy Sci. 90:38383845 .

Broderick, G. A., and W. J. Radloff. 2004. Effect of molasses supplementation on the production of lactating dairy cows fed diets based on alfalfa and corn silage. J. Dairy Sci. 87:2997-3009.

Cherney, D. J. R., J. H. Cherney, and L. E. Chase. 2003. Influence of dietary nonfiber carbohydrate concentration and supplementation of sucrose on lactation performance of cows fed fescue silage. J. Dairy Sci. 86:3983-3991.

DeFrain, J. M., A. R. Hippen, K. F. Kalscheur, and D. J. Schingoethe. 2006. Feeding lactose to increase ruminal butyrate and the metabolic status of transition dairy cows. J. Dairy Sci. 89:267-276.

Devillard, E., F. M. McIntosh, C. J. Newbold, and R. J. Wallace. 2006. Rumen ciliate protozoa contain high concentrations of conjugated linoleic acids and vaccenic acid, yet do not hydrogenate linoleic acid or desaturate stearic acid. Br. J. Nutr. 96:697-704.

Eschenlauer, S. C. P., N. McKain, N. D. Walker, N. R. McEwan, C. J. Newbold, and R. J. Wallace. 2002. Ammonia production by ruminal microorganisms and enumeration, isolation, and characterization of bacteria capable of growth on peptides and amino acids from the sheep rumen. Appl. Environ. Microbiol. 68:4925-4931.

Ferreira, G., and D. R. Mertens. 2005. Chemical and physical characteristics of corn silages and their effects on in vitro disappearance. J. Dairy Sci. 88:4414-4425.

Firkins, J L, M. L. Eastridge, N. R. St-Pierre, and S. M. Noftsger. 2001. Effects of grain variability and processing on starch utilization by lactating dairy cattle. J. Anim. Sci. 79(E Suppl.):E218-E238.

Firkins, J. L., A. N. Hristov, M. B. Hall, G. A. Varga, and N. R. StPierre. 2006. Integration of ruminal metabolism in dairy cattle. J. Dairy Sci. 89(E Suppl.):E31-E51.

Golombeski, G. L., K. F. Kalscheur, A. R. Hippen, and D. J. Schingoethe. 2006. Slow-release urea and highly fermentable sugars in diets fed to dairy cows. J. Dairy Sci. 89:4395-4403.

Griswold, K. E., G. A. Apgar, J. Bouton, and J. L. Firkins. 2003. Effects of urea infusion and ruminal degradable protein concentration on microbial growth, digestibility, and fermentation in continuous culture. J. Anim. Sci. 81:329-336.

Hall, M. B., W. H. Hoover, J. P. Jennings, and T. K. Miller Webster. 1999. A method for partitioning neutral-detergent soluble carbohydrates. J. Sci. Food Agric. 79:2079-2086.

Harvatine, D. I., J. L. Firkins, and M. L. Eastridge. 2002. Whole linted cottonseed as a forage substitute fed with ground or steamflaked corn: Digestibility and performance. J. Dairy Sci. 85:1976-1987.

Harvatine, K. J., and M. S. Allen. 2006a. Effects of fatty acid supplements on milk yield and energy balance of lactating dairy cows. J. Dairy Sci. 89:1081-1091.
Harvatine, K. J., and M. S. Allen. 2006b. Effects of fatty acid supplements on feed intake, and feeding and chewing behavior of lactating dairy cows. J. Dairy Sci. 89:1104-1112.

Hristov, A. N., J. K. Ropp, K. L. Grandeen, S. Abedi, R. P. Etter, A. Melgar, and A. E. Foley. 2005. Effect of carbohydrate source on ammonia utilization in lactating dairy cows. J. Anim. Sci. 83:408-421.

Ipharraguerre, I. R., and J. H. Clark. 2003. Usefulness of ionophores for lactating dairy cows: A review. Anim. Feed Sci. Technol. 106:39-57.

Jenkins, T. C., and M. A. McGuire. 2006. Major advances in nutrition: Impact on milk composition. J. Dairy Sci. 89:1302-1310.

Leonardi, C., and L. E. Armentano. 2007. Short communication: Feed selection by dairy cows fed individually in a tie-stall or as a group in a free-stall barn. J. Dairy Sci. 90:2386-2389.

Leonardi, C., F. Giannico, and L. E. Armentano. 2005. Effect of water addition on selective consumption (sorting) of dry diets by dairy cattle. J. Dairy Sci. 88:1043-1049.

Maiga, H. A., D. J. Schingoethe, and F. C. Ludens. 1995. Evaluation of diets containing supplemental fat with different sources of carbohydrates for lactating dairy cows. J. Dairy Sci. 78:11221130.

Mansfield, H. R., and M. D. Stern. 1994. Effects of soybean hulls and lignosulfonate-treated soybean meal on ruminal fermentation in lactating dairy cows. J. Dairy Sci. 77:1070-1083.

McGuffey, R K, L. F. Richardson, and J. I. D. Wilkinson. 2001. Ionophores for dairy cattle: Current status and future outlook. J. Dairy Sci. 84(E Suppl.):E194-E203.

Murphy, M. R., A. W. P. Geijsel, E. C. Hall, and R. D. Shanks. 1997. Dietary variety via sweetening and voluntary feed intake by lactating dairy cows. J. Dairy Sci. 80:894-897.

Nagaraja, T. G., C. J. Newbold, C. J. Van Nevel, and D. I. Demeyer. 1997. Manipulation of rumen fermentation. Pages 523-632 in The Rumen Microbial Ecosystem. P. N. Hobson and C. S. Stewart, ed. Chapman and Hall, London, UK.

National Research Council. 1989. Nutrient Requirements of Dairy Cattle. 6th rev. ed. Natl. Acad. Sci., Washington, DC.

National Research Council. 2001. Nutrient Requirements of Dairy Cattle. 7th rev. ed. Natl. Acad. Sci., Washington, DC.

Odongo, N. E., R. Bagg, G. Vessie, P. Dick, M. M. Or-Rashid, S. E. Hook, J. T. Gray, E. Kebreab, J. France, and B. W. McBride. 2007. Long-term effects of feeding monensin on methane production in lactating dairy cows. J. Dairy Sci. 90:1781-1788.

Pantoja, J., J. L. Firkins, and M. L. Eastridge. 1996. Fatty acid digestibility and lactation performance by dairy cows fed fats varying in degree of saturation. J. Dairy Sci. 79:429-437.

Phipps, R. H., J. I. D. Wilkinson, L. J. Jonker, M. Tarrant, A. K. Jones, and A. Hodge. 2000. Effect of monensin on milk production of Holstein-Friesian dairy cows. J. Dairy Sci. 83:2789-2794.

Piwonka, E. J., J. L. Firkins, and B. L. Hull. 1994. Digestion in the rumen and total tract of forage-based diets with starch or dextrose supplements fed to Holstein heifers. J. Dairy Sci. 77:1570-1579.

Reveneau, C., C. V. D. M. Ribeiro, M. L. Eastridge, N. R. St-Pierre, and J. L. Firkins. 2005. Processing whole cottonseed moderates fatty acid metabolism and improves performance by dairy cows. J. Dairy Sci. 88:4342-4355.

Ribeiro, C. V. D., M. L. Eastridge, J. L. Firkins, N. R. St-Pierre, and D. L. Palmquist. 2007. Kinetics of fatty acid biohydrogenation in vitro. J. Dairy Sci. 90:1405-1416.

Ribeiro, C. V. D. M., S. K. R. Karnati, and M. L. Eastridge. 2005. Biohydrogenation of fatty acids and digestibility of fresh alfalfa or alfalfa hay plus sucrose in continuous culture. J. Dairy Sci. 88:4007-4017

Russell, J. B., and A. J. Houlihan. 2003. Ionophore resistance of ruminal bacteria and its potential impact on human health. FEMS Microbiol. Rev. 27:65-74.

Sannes, R. A., M. A. Messman, and D. B. Vagnoni. 2002. Form of rumen-degradable carbohydrate and nitrogen on microbial protein synthesis and protein efficiency of dairy cows. J. Dairy Sci. 85:900-908.

Shingfield, K. J., C. K. Reynolds, G. Hervás, J. M. Griinari, A. S Grandison, and D. E. Beever. 2006. Examination of the persis- 
tency of milk fatty acid composition responses to fish oil and sunflower oil in the diet of dairy cows. J. Dairy Sci. 89:714-732.

Sukhija, P. S., and D. L. Palmquist. 1988. Rapid method for determination of total fatty acid content and composition of feedstuffs and feces. J. Agric. Food Chem. 36:1202-1206.

Tyrrell, H. F., and J. T. Reid. 1965. Prediction of the energy value of cow's milk. J. Dairy Sci. 48:1215-1223.

Van Soest, P. J., J. B. Robertson, and B. A. Lewis. 1991. Methods for dietary fiber, neutral detergent fiber, and nonstarch polysac- charides in relation to animal nutrition. J. Dairy Sci. 74:35833597.

Weiss, W. P. 1993. Predicting energy values of feeds. J. Dairy Sci. 76:1802-1811.

Williams, C. H., D. J. David, and O. Iismaa. 1962. The determination of chromic oxide in feces samples by atomic absorption spectrophotometry. J. Agric. Sci. 59:381-385.

Wu, Z., and J. T. Huber. 1994. Relationship between dietary fat supplementation and milk protein concentration in lactating cows: A review. Livest. Prod. Sci. 39:141-155. 